\title{
Marek Hendrykowski Jeszcze o adaptacji. W odpowiedzi Sewerynie Wysłouch
}

\begin{abstract}
Hendrykowski Marek, Jeszcze o adaptacji. W odpowiedzi Sewerynie Wysłouch [Once more on adaptation: A response to Seweryna Wysłouch]. „Przestrzenie Teorii" 23. Poznań 2015, Adam Mickiewicz University Press, pp. 173-182. ISBN 978-83-232-2920-9. ISSN 16446763. DOI 10.14746/pt.2015.23.11.

Marek Hendrykowski's paper provides certain remarks and necessary explanations in response to Seweryna Wysłouch's polemic ("A film adaptation - a translation or montage?", published in Przestrzenie Teorii no. 22, 2014).
\end{abstract}

„Czy warto dyskutować i polemizować?” - pyta w swoim artykule polemicznym prof. Seweryna Wysłouch („Przestrzenie Teorii” nr 22, 2014). I na postawione przez siebie pytanie odpowiada następująco: „Podobno dyskusje jeszcze nikogo nie przekonały. A jednak czym byłaby humanistyka bez wymiany myśli, merytorycznych sporów, wzajemnych inspiracji?”. Otóż to. Podzielam powyższe zdanie w całej rozciągłości i z tego względu postanowiłem raz jeszcze wniknąć w meritum dzielącej nas różnicy zdań, która stanowi powód naukowej kontrowersji - z myślą o tym, że być może otwiera się dzięki temu szansa na nowe spojrzenie i odkrywcze podejście do frapującej skądinąd problematyki adaptacji (nie tylko filmowej) w jej współczesnym wydaniu.

Dodam jeszcze tylko, iż czuję się osobiście wyróżniony i zaszczycony faktem, iż mój skromny artykuł Adaptacja jako przekład intersemiotycz$n y$ („Przestrzenie Teorii” nr 20, 2013) doczekał się wnikliwego odczytania i dyskusji ze strony uznanej znawczyni problematyki adaptacji i powinowactw sztuk, jaką od lat jest Seweryna Wysłouch. W takich chwilach już sam fakt polemiki - że nie wspomnę o stanowiącym jej istotę meritum sprawia autorowi radość i satysfakcję, dając asumpt do ponownego przemyślenia poruszanych zagadnień: $\mathrm{w}$ tym przypadku złożonej problematyki adaptacji w jej wydaniu zarówno historycznym, jak i dzisiejszym. Tyle koniecznego wstępu, po którym przejdźmy ad rem.

\section{W kręgu pojęcia montażu}

„Adaptacja filmowa - przekładem czy montażem?” - pyta w tytule swego artykułu Autorka. Z perspektywy badawczej, jaką przyjąłem, problem wydaje się pozorny, a pytanie retoryczne. Nie dostrzegam tutaj 
istotnej sprzeczności, bowiem, w moim przekonaniu, przeciwstawieniem przekład - montaż w odniesieniu do zjawiska adaptacji filmowej rządzi nie zasada rozłączności (jedno albo drugie), lecz przeciwnie zasada koniunkcji (i jedno, i drugie). Obie możliwe odpowiedzi (adaptacja jako przekład oraz adaptacja jako szeroko rozumiany montaż) uważam przeto za jednakowo poprawne, zasadne i równouprawnione.

Myślenie o adaptacji w kategoriach przekładu intersemiotycznego nie wyklucza myślenia montażowego. Dzięki repertuarowi przypisanych im i przemawiających za nimi argumentów, oba modele teoretyczne mają tożsamą wartość logiczną i moc wyjaśniającą. Teoria adaptacji jako swoistego rodzaju intersemiotycznego przekładu i teoria montażowa różnią się natomiast zestawem narzędzi poznawczych będących na wyposażeniu badacza, co wydatnie zwiększa jego szanse wnikliwszego poznania studiowanego zjawiska nie tylko na gruncie translatologii, lecz również $\mathrm{w}$ wielorakim powiązaniu z praktyką filmowej adaptacji.

W tym miejscu słowo koniecznego wyjaśnienia. Sęk w tym, że operacyjna definicja montażu, jaką na użytek własnych rozważań przedstawiłem w moim artykule („montaż, czyli wybór i kombinacja ruchomych obrazów - tworzący nową, ekwiwalentną względem pierwowzoru całość tekstową"), nasuwa nieodparcie skojarzenie, iż chodzi tutaj o termin odnoszący się wyłącznie do filmu. W punkcie wyjścia tak zresztą było i powinno być, skoro montaż od samego początku jest pojęciem swoistym właśnie dla filmu - wykreowanym na gruncie sztuki i kultury filmowej. Skojarzenie, o jakim mowa, wywołują „ruchome obrazy” (w domyśle wizualne i audialne), z których strumienia składa się każdy film. Montaż ruchomych obrazów, o który mi szło, należy rozumieć o wiele szerzej. Nie jest on warsztatową czynnością montowania materiału wizualnego bądź audiowizualnego, lecz złożonym, twórczym procesem myślowym towarzyszącym adaptacji i składającym się na jej finalny rezultat.

Owszem chodzi tu o ruchome obrazy, ale nie tylko. I na dodatek jeszcze $\mathrm{z}$ ich przypisaniem zarezerwowanym do samego efektu adaptacji. W odniesieniu do adaptacji filmowej określenie „ruchome obrazy” staje się oczywiste. Kino zarówno ery niemej, jak i dźwiękowej w wielkiej mierze przyczyniło się do rozwoju kultury adaptacji. W widowisku ekranowym percypujemy strumień ruchomych obrazów. Po stronie pierwotekstu, będącego obiektem adaptacji, mamy natomiast tyle heterogenicznych elementów, ile da się wskazać w domenach (literatura, teatr, opera, musical, malarstwo, happening, piosenka, pantomima, taniec, komiks, fotografia, gra komputerowa etc.), z których adaptator czerpie z myślą o utworze filmowym. Nasuwa się w tym miejscu kolejna wątpliwość i pytanie: czy wyłącznie filmowym? 
Adaptacja - jako szeroko rozpowszechniona forma praktyki kulturowej i intertekstualny proces przystosowania - dotyczy przecież nie tylko filmu, nie tylko literatury i nie tylko sztuki. Nie ogranicza się ona bynajmniej do fikcji fabularnej i prozy beletrystycznej, z którą bywa najczęściej kojarzona. Adaptacja jako proces i jako wytwór ogarnia swym zasięiem bez porównania więcej. Adaptowaniu we współczesnej kulturze podlegają bowiem najróżniejsze odmiany tekstów: werbalnych i niewerbalnych, literackich, nieliterackich, artystycznych i nieartystycznych.

Wskazując na użyteczność pojęcia „montażu” w kontekście współczesnych badań nad adaptacją, nie proponuję (pozornej) metodologicznej alternatywy polegającej na odrzuceniu koncepcji „translatologicznej” i zastąpieniu jej koncepcją „montażową”. Optuję za umiejętnym połączeniem obu sposobów ujmowania adaptacji - jako sposobów komplementarnych. Adaptacja filmowa stanowi, w moim przekonaniu, taki rodzaj przekładu intersemiotycznego, w którym podstawowa funkcja przypada montażowi (to znaczy wyborowi i kombinacji heterogenicznych elementów utworu, zachodzących na wielu poziomach jego konstrukcji znaczeniowej). Elementami tymi są: makroobrazy i mikroobrazy, wielkie figury semantyczne, tropy, sceny, elementy fabuły, sposoby narracji, rodzaje, gatunki i odmiany gatunkowe, archetypy, memy kulturowe etc.

Seweryna Wysłouch słusznie upomina się o uwzględnienie kategorii dominanty strukturalnej. Najlepiej nadaje się do tego właśnie świadomość „montażowa”. Montaż i zabiegi montażowe, będące pochodną kreacji rozgrywającej się w wyobraźni adaptatora, odnoszą się do różnych aspektów ekranowego widowiska. $\mathrm{Z}$ punktu widzenia badacza użyteczność studiowania operacji montażowych polega na tym, iż pozwalają one opisać nie tylko zmiany dokonane przez niego w świecie przedstawionym pierwowzoru czy w jego strukturze narracyjnej, lecz również te - najczęściej wymykające się analizie zainteresowanej problematyką „przekładu” aspekty adaptacji, które obejmują w utworze filmowym takie elementy, jak: ruch, rytm, tempo akcji, kolorystyka (z paletą czarno-białą włącznie), filmowa interpunkcja, frazowanie, aranżacja i orkiestracja wiązki elementów wizualnych i dźwiękowych, synestezja etc.

\section{W kręgu praktyki twórczej}

Tym, który pierwszy „montuje” przyszły film, jest scenarzysta-adaptator. Od jakości pracy, którą wykonuje, zależy potem na planie i na ekranie bardzo wiele. Uważna obserwacja rezultatu jego wysiłków na etapie scenariusza pozwala dostrzec trafność decyzji dotyczących wyboru i kom- 
binacji poszczególnych elementów bądź przeciwnie mechaniczne ich przenoszenie i układanie $\mathrm{w}$ drodze banalnej transpozycji zawartości pierwotekstu. Ten często popełniany przez adaptatorów błąd uświadamia nam, że nie istnieje coś takiego, jak adaptacja w skali 1:1, w wyniku której utwór adaptowany staje się własną ekranową imitacją - filmowym faksymile. Ponowny montaż całości wymaga demontażu struktury pierwowzoru. Zaadaptowanie czegokolwiek polega na ponownym wykonaniu adaptowanej struktury w odmiennym języku i tworzywie.

Szanowna Polemistka kieruje mnie w stronę koncepcji Romana Jakobsona. Świetny to adres. Z jednym wszakże ważnym zastrzeżeniem: nie wiadomo, czy ma to być dawny Jakobson z pierwszej połowy lat trzydziestych, który w roku 1933 opublikował na łamach praskiego czasopisma „Listy pro umĕni a kritiku” słynne studium zatytułowane Upadek filmu?1. Czy może późniejszy Jakobson rozwijający krok po kroku prekursorską ideę panlingwistyki jako dwudziestowiecznej semiotyki uniwersalnej ${ }^{2}$. W przypadku pierwszego z Jakobsonowskich adresów powstaje kłopot $\mathrm{z}$ jego nieaktualnością. Osobiście wolałbym wybrać się pod drugi z nich - ze względu na prekursorski, o dekady wyprzedzający myślenie $\mathrm{w}$ kategoriach kognitywizmu wspomniany koncept panlingwistyki, której badacz poświęcał wiele uwagi w późniejszych dociekaniach i pracach.

$\mathrm{W}$ swoim czasie (zaczerpnięty z wcześniejszej idei Lwa Kuleszowa „materiałem kinematografu są rzeczy realne” i dodatkowo poparty powołaniem się na św. Augustyna) zaprezentowany przez Romana Jakobsona w pierwszej połowie lat trzydziestych koncept zamiany rzeczy optycznych i akustycznych w znaki był czymś rewelacyjnym. Dzisiaj myślimy już o nim inaczej, dostrzegając ryzyko uproszczeń i prowizorki metodologicznej związane $\mathrm{z}$ wielce problematyczną $\mathrm{i}$ bynajmniej nieoczywistą „realnością" procesów semiozy w komunikacji nie tylko filmowej, ale dużo szerzej - audiowizualnej. Wirtualność cyfrowych symulakrów sporo nam w tej materii dała do myślenia i nauczyła.

Trawestując cytat stanowiący pierwsze zdanie przywołanego artykułu Jakobsona: „Jesteśmy leniwi i pozbawieni ciekawości” - szczęśliwie nie jesteśmy ani leniwi, ani pozbawieni ciekawości. Wprost przeciwnie, zagadnieniem niebywale nośnym poznawczo, intrygującym i odkrywanym wciąż na nowo stał się dla dzisiejszych badaczy zarówno język ruchomych obrazów, jak i - co może w pierwszej chwili zaskakiwać - badane w nowych kontekstach swego występowania zjawisko adaptacji. Adaptuje

1 R. Jakobson, Upadek filmu?, przeł. Cz. Dondziłło, [w:] Estetyka i film, red. A. Helman, Warszawa 1972, s. 93-102.

2 R. Jakobson, W poszukiwaniu istoty języka. Wybór pism, t. 1-2, wybór, redakcja naukowa i wstęp M.R. Mayenowa, Warszawa 1989. 
się bowiem nadal wszechstronnie i na potęgę: nie tylko na ekran, ale i z ekranu. Adaptowanie stanowi jedno z podstawowych działań służących makroprocesowi odtwarzania kultury - dokonującemu się na różnych jej poziomach i w wielu możliwych obiegach.

Tyle że adaptuje się inaczej niż w czasach Przeminęło $z$ wiatrem, Popiołu i diamentu, Samotności długodystansowca czy Rękopisu znalezionego $w$ Saragossie. Do klasycznego dawniej wariantu "dwutekstu” adaptacyjnego (pierwowzór i jego ekranizacja) doszły dzisiaj nowe rozwiązania, sposoby i możliwości: adaptowanie zwrotne, audializacja (m.in. adaptacje dźwiękowe w formie audiobooków), poliadaptacja (adaptacja wielotekstowa łącznie $\mathrm{z}$ fenomenem hybryd adaptacyjnych) oraz multiadaptacja (adaptacja wielokrotna), a ponadto fan filming i fan writing.

Film, który nigdy nie miał monopolu na adaptację, dziś nie ma go tym bardziej. Wysiłki filmowców awangardystów (od Wiertowa począwszy) sprawiły, że autonomia sztuki filmowej stała się - przynajmniej koncepcyjnie - wartością uwolnioną od pierwiastka literackiego. Dawny antagonizm filmu i literatury ustąpił miejsca kooperacji obu dziedzin. Niegdyś obie traciły, obecnie obie upatrują dla siebie korzyść we współdziałaniu. Adaptowanie literatury na ekran uchodziło dla wielu za działanie wtórne i regresywne względem autonomicznych aspiracji sztuki filmowej. Trudno obecnie w środowisku filmowym natrafić na kogoś, kto nadal uważa, że tak właśnie jest. Pogląd ten szczęśliwie trafił dzisiaj do lamusa porzuconych przesądów, podobnie jak niechęć części pisarzy do ekranizacji ich własnych utworów.

Adaptacja filmowa nieprzerwanie ewoluuje nie tylko w liczących sobie ponad sto dwadzieścia lat dziejach kinematografii, lecz również w dziejach kultury przełomu XX i XXI wieku. Praktyka adaptowania, z jaką aktualnie się stykamy, wymusza na teorii tego zjawiska konieczność dostosowania jej narzędzi i metod badawczych. Powinny one podlegać ciągłej rewizji, modyfikacji i przepracowaniu. Z myślą o tym, iż fenomen adaptacji w jego współczesnych, ciągle zmieniających się postaciach - by nie popaść w anachronizm - należy badać za pomocą odpowiednich instrumentów, kierując się przy tym dążeniem do stworzenia stale poszerzanej o nowe zjawiska i doświadczenia teorii praktyki adaptacyjnej.

\section{W przestrzeni teorii}

Nie jest dziełem przypadku, iż trzy dekady temu znakomity amerykański teoretyk filmu Dudley Andrew określił problematykę „adaptacji” jako jedno z dziewięciu fundamentalnych zagadnień nauki o filmie. 
Wtedy pogląd ten brzmiał poniekąd jak nieuzasadnione proroctwo. Dzisiaj widać, że Andrew miał w swej prognozie rację. Od tamtego czasu zmieniło się bardzo wiele zarówno w samej praktyce adaptowania, jak i w sferze naukowej refleksji nad adaptacją. Po prostu w odmienny sposób na nią patrzymy, coraz mniej uwagi poświęcając kluczowej dawniej kwestii „wierności” i „twórczej zdrady”, za to odkrywając rzeczy wcześniej pomijane bądź uznane za nieważne.

$\mathrm{W}$ pracach poruszających tematykę adaptacji pochodzących z nowego i najnowszego okresu widać bardzo wyraźnie, iż praktyka twórcza współczesności wywarła znaczący wpływ na teorię. Dokonała się w niej głęboka reorientacja $\mathrm{w}$ badaniach nad procesami adaptowania, którą w wielkim skrócie można umownie określić jako zwrot w stronę kulturowej teorii adaptacji.

Zwrot, o którym mowa, pociąga za sobą rozliczne konsekwencje. $\mathrm{Z}$ mojego punktu widzenia, o czym będę jeszcze szerzej mówił $\mathrm{w}$ dalszej części, przy wszelkich korzyściach płynących z kulturowej teorii adaptacji, niebezpieczne jako droga do nikąd bywa porzucanie przez nią perspektywy semiotycznej - rzekomo ograniczającej refleksję nad adaptacją i adaptowaniem. Nie sposób milcząco przejść do porządku nad faktem, iż ortodoksyjnie uprawiana „kulturowa” refleksja nad tą problematyką tu i ówdzie wykazuje ortodoksyjną skłonność do absolutyzowania własnych rozstrzygnięć, które traktuje się jako „lepsze” od semiotycznych, co stanowi oczywiste nieporozumienie.

Podkreślmy zatem, że 1) język ruchomych obrazów, 2) utwór będący adaptacją oraz 3) tekstowy punkt widzenia - stanowią podstawową triadę w naukowej refleksji nad adaptowaniem jako metodologiczny układ jej odniesienia. W sferze tak prowadzonej refleksji badawczej dotychczasowy model adaptacyjnego „przekładu” konkuruje, ale nie wyklucza się z modelem adaptacji jako „montażu”. Mowa oczywiście o sferze teorii operującej wysokim poziomem wyabstrahowania, która skądinąd niekoniecznie respektuje w swych ustaleniach to, co dzieje się w praktyce adaptacji.

Codzienna praktyka twórcza w sferze adaptacji filmowej i szerzej audiowizualnej potwierdza, że doszło do istotnego przesunięcia akcentów. Relacja „dzieło - dzieło" nie jest już jedynym godnym uwagi układem odniesienia. Współcześnie liczą się o wiele bardziej te zabiegi adaptacyjne, które uruchamiają kulturowy kontekst, odsyłając widza nie do samego pierwowzoru (aby uniknąć mimowolnego normatywizmu związanego z określeniem „pierwowzór”, wolałbym tu mówić raczej o „pierwotekście”), lecz „na zewnątrz” w stronę intertekstualnej gry znaczeń i związanej z nią swobody adaptowania, która na taką skalę wcześniej nie występowała. 
Problem, jaki mam ze stanowiskiem zajmowanym przez Sewerynę Wysłouch w kwestii adaptacji filmowej, polega na konsekwentnym zawężeniu przez nią refleksji do pola metodologii literaturoznawstwa. Uważam, że wyrastająca z nauki o literaturze wieloletnia tradycja badań nad adaptacją filmową ze wszech miar zasługuje na uznanie. Odegrała bowiem doniosłą rolę $\mathrm{w}$ zrozumieniu tego fenomenu. Stosowana jednak w sposób schematyczny i rutynowy straciła z czasem sporo ze swej pierwotnej świeżości spojrzenia i produktywności intelektualnej. Dzisiaj zdolna jest ona objaśnić tylko cząstkę tego wszystkiego, co dzieje się na co dzień w praktyce adaptowania.

Opowiadam się tutaj nie za prymatem jakiejkolwiek jednej - „lepszej" i uprzywilejowanej względem innych - metody badawczej, lecz za metodologicznym, interdyscyplinarnym eklektyzmem, polegającym na czerpaniu inspiracji badawczej zewsząd i komplementarnym wykorzystywaniu rozmaitych użytecznych instrumentów i sposobów przydatnych w studiach nad adaptacją - podkreślam - nie tylko artystyczną i nie tylko filmową.

Najskuteczniejszym z tych sposobów, scalających nasze dążenia, powinna się okazać teoria praktyki adaptowania: uprawiana nie jako obowiązująca każdego użytkownika „instrukcja obsługi”, lecz jako pogłębiona kulturowa refleksja nad złożonością fenomenu adaptowania ściśle powiązana $\mathrm{z}$ funkcjonowaniem zjawiska adaptacji we współczesnym świecie. Tym, co najbardziej nośne i pociągające w procesie adaptowania, okazuje się oryginalność i inwencja coraz to nowych jego modeli i wariantów składająca się na urzekającą odbiorcę adaptacyjną „serendipity”3. Uwagę tę chętnie rozszerzyłbym na poetykę historyczną adaptacji filmowej badanej jako ciągła ewolucja praktyk adaptacyjnych: od Oblanego ogrodni$k a$ braci Lumière (1895) do Adaptacji Spike'a Jonze (2002).

\section{W kręgu semiotyki kultury}

Rozważania i propozycje zawarte w moim artykule zmierzały do zbudowania i przerzucenia metodologicznego pomostu między odseparowanymi od siebie dziedzinami sztuki, jak również - między terytoriami naukowej refleksji nad nimi. Dążenie to koresponduje z najnowszymi trendami współczesnej refleksji okołoadaptacyjnej uprawianej przez międzynarodowe grono takich badaczy, jak: Seymour Chatman ${ }^{4}$, Wacław

3 Twórca tego wdzięcznego i wieloznacznego pojęcia Horace Walpole (1754) mawiał o nim „fortunate happenstance” lub „pleasant surprise”.

${ }^{4} \mathrm{~S}$. Chatman, Coming to Terms. The Rhetoric of Narrative in Fiction and Film, Ithaca-New York 1990. 
Osadnik ${ }^{5}$, Brian McFarlane ${ }^{6}$, brytyjski duet autorski Deborah Cartmell \&Imelda Whelehan ${ }^{7}$, James Naremore ${ }^{8}$, Julie Sanders ${ }^{9}$, Robert Stam ${ }^{10}$, Linda Hutcheon ${ }^{11} \mathrm{i}$, last but not least, Alicja Helman ${ }^{12}$.

W swoich najlepszych przejawach dzisiejsza refleksja naukowa nad adaptacją - nie przestając czerpać z inspiracji literaturoznawczych - odnajduje nowe sposoby opisu, analizy i interpretacji rozmaitych zjawisk związanych $\mathrm{z}$ adaptowaniem $\mathrm{w}$ kulturze współczesnej. Dostrzega przy tym swoistość reguł języka ruchomych obrazów i korespondencję semantyczną zachodzącą na wszystkich czterech jego poziomach: od kinetycznego, poprzez morfologiczny, figuralny, aż do wielkich figur semantycznych.

Wskazane przeze mnie w artykule Adaptacja filmowa jako przekład intersemiotyczny operacje przekładowo-montażowe poszerzają dotychczasowy klasyczny ich rejestr (substytucja, redukcja, addycja, amplifikacja) o trzy kolejne warianty: inwersję, transakcentację i kompresję. Warto przy tym nadmienić, iż wszystkich siedem wariantów dotyczy zarówno tkanki językowej tekstu, jak i struktury głębokiej zawartych w nim znaczeń. Pod tym względem nie ma pomiędzy tymi operacjami istotnej różnicy funkcjonalnej. Cokolwiek dzieje się na powierzchni tekstu, ma to swoje semantyczne konsekwencje w jego warstwie głębokiej.

I vice versa, gruntowna przebudowa zamierzona przez adaptatora wewnątrz konstrukcji pierwotekstu tak czy inaczej musi znaleźć swoje odzwierciedlenie i wyraz na powierzchni tekstu wtórego. Innymi słowy, nie może ona pozostać dla widza niewidoczna i niesłyszalna. „Montaż” $\mathrm{w}$ tym rozumieniu jako złożony, wielofunkcyjny rezultat procesu adaptacji angażuje wszystkie poziomy i aspekty nowego utworu - również takie (ruch, rytm, ekspresja światła i cienia, faktura obrazu czy tonacja kolorystyczna), które $\mathrm{z}$ wielkim trudem poddają analizie semiotycznej prowadzonej w odniesieniu do adaptowanego pierwotekstu.

${ }^{5}$ W. Osadnik, Adaptacja filmowa jako przekład, [w:] Kino wedtug Alicji, red. W. Godzic, T. Lubelski, Kraków 1995.

${ }^{6}$ B. McFarlane, Novel into Movies. An Introduction to the Theory of Adaptation, Oxford 1996.

7 D. Cartmell, I. Whelehan, Adaptations. From Text to Screen, Screen to Text, London-New York 1999.

8 J. Naremore, Film Adaptation, New Brunswick 2000.

9 J. Sanders, Adaptation and Appropriation (The New Critical Idiom), London 2005.

${ }^{10}$ R. Stam, Literature through Film. Realism, Magic and the Art of Adaptation, Oxford 2005.

${ }^{11}$ L. Hutcheon, A Theory of Adaptation, London-New York 2006.

12 Zob. A. Helman, Twórcza zdrada. Filmowe adaptacje literatury. Wydanie nowe, zmienione i poszerzone, Poznań 2014. 
Kapitalnie przed z górą półwieczem uchwycił tę trudność Umberto Eco w recenzji książki Luigiego Chiariniego"13, pisząc: „Chiarini kładzie nacisk na podstawową różnicę pomiędzy sztuką wykorzystującą słowa-pojęcia a sztuką wykorzystującą obrazy. Trzeba zauważyć, że w tym pierwszym przypadku (literatura) odbiorca reaguje na znak językowy, który wprawdzie odbiera się w postaci zmysłowej, ale który można wykorzystać jedynie na drodze dość skomplikowanej, choć spontanicznej operacji, polegającej na eksploracji «pola semantycznego» związanego z tym znakiem, aż do momentu, w którym, w powiązaniu z informacjami płynącymi z kontekstu, odpowiednio zrozumiany znak wywoła również pewną liczbę obrazów zdolnych do emocjonalnego pobudzenia odbiorcy. W przeciwieństwie do tego, w przypadku pobudzania za pomocą obrazu (a właśnie $\mathrm{z}$ takim przypadkiem mamy do czynienia w filmie) przebieg jest dokładnie odwrotny: pierwszym bodźcem jest wrażenie zmysłowe, jeszcze nie zracjonalizowane i konceptualnie nieuformowane, odbierane wraz z całym ładunkiem emocjonalnym, jaki obraz ze sobą niesie. [...] Te rzucające się w oczy różnice są już dostatecznie wymowne, aby odwieść nas od zbyt łatwych porównań kina i prozy narracyjnej"14.

\section{W kręgu aksjologii adaptacji}

Z niemałą trudnością przychodzi nam się pogodzić z myślą, że sztuka adaptacji może dotyczyć nie tylko artystycznych aspiracji Dziesiątej Muzy, lecz także obejmować swym zasięgiem szeroki rejestr domen kultury popularnej, z natury rzeczy niekojarzonych ze sztuką wysokiego lotu. A tak przecież z praktyką adaptowania obecnie bywa - i to częściej, niż się wielu $\mathrm{z}$ nas wydaje.

Co różni dobrą adaptację od złej? Różni ją wiele rzeczy: od istotnych drobnych szczegółów do generalnej koncepcji zaadaptowania. Istnieje jednak przy tym pewna znamienna prawidłowość. Chybiona adaptacja - niczym wadliwy projekt architektoniczny - okazuje się utworem chybionym, konstruktem źle pomyślanym przez projektanta. Jeśli dana adaptacja stanowi zły „przekład intersemiotyczny”, winę za to ponosi źle przeprowadzony „montaż” (resp. nietrafny wybór adaptowanych elementów i pozbawiona nośności semantycznej byle jaka ich kombinacja).

${ }^{13}$ L. Chiarini, Arte e tecnica del film, Bari 1962.

${ }^{14}$ U. Eco, Kino i literatura: struktura narracyjnej intrygi, [w:] tenże, Sztuka, przeł. P. Salwa, M. Salwa, Kraków 2008, cyt. s. 205-206. Cytowana wypowiedź włoskiego semiologa pochodzi z roku 1962. 
Dobrą adaptację - nie mówiąc o znakomitej czy kongenialnej - poznajemy po wartości naddanej, jaką wnosi w stosunku do swego pierwotekstu bądź wiązki pierwotekstów. Nowa struktura czerpie z adaptowanego materiału o wiele więcej niż tylko: atrakcyjny temat, wątki fabularne, przebieg akcji czy sylwetki bohaterów opowieści. Nowa wartość, jaką kreuje adaptacja, ma swoje źródło zarówno w podobieństwach, jak i różnicach. Jakobson powiedziałby, iż tu i tam wchodzi w grę ekwiwalencja. Eco natomiast wskazałby na wagę odkrywania „homologii strukturalnych między zjawiskami należącymi do różnych kategorii, a jednak dającymi się opisać i zinterpretować za pomocą modeli strukturalnych, które w swym ogólnym kształcie są jednakowe"15.

Dzieło będące adaptacją koresponduje ze swoim pierwowzorem na różnych polach twórczej inspiracji. I odwrotnie, odtwórczy stosunek do adaptowania pociąga za sobą jego bezproduktywność polegającą na braku wartości nowo wytworzonej.

Jako lektor scenariuszowy na co dzień mam do czynienia $\mathrm{z}$ wieloma pisanymi dzisiaj scenariuszami, z których niemałą część stanowią adaptacje. Dostrzegam w nich postępujący regres w dziedzinie umiejętności adaptowania - nie tylko literatury. Na podstawie tych obserwacji doszedłem do wniosku, że konieczne jest ponowne zajęcie się teorią praktyki adaptacji. $\mathrm{O}$ ile bowiem adaptatorzy nie muszą znać teorii ${ }^{16}$, o tyle demontaż i montaż pierwotekstu dokonany nieumiejętnie przez kiepskiego scenarzystę zbyt często prowadzi do prymitywnej symplifikacji, a bywa, że i do adaptacyjnego barbarzyństwa. Kontentuje go, jak się wydaje, już sam fakt adaptacji bez świadomości, że istniało i nadal istnieje coś takiego, jak kultura adaptacji i kunszt adaptowania. Każdy potrafi rozebrać i rozmontować zegarek, nie każdy natomiast umie, element po elemencie, złożyć jego precyzyjny mechanizm w nadal działającą całość.

$\mathrm{Na}$ zakończenie raz jeszcze wyrażam podziękowanie Sewerynie Wysłouch za inspirujące uwagi, dopowiedzenia i wątpliwości zawarte w jej polemicznym artykule.

15 Tamże, s. 207.

16 Niektórzy z nich - mówię to na podstawie lektury nieudanych scenariuszy - są jak studenci, którzy potykają się w swoich pracach pisemnych o fundamentalne problemy metodologiczne, nie mając najmniejszej świadomości, że takowe istnieją. 